\title{
Diet Of Peary Caribou, Banks Island, N.W.T.
}

\author{
CHRISTOPHER C. SHANK ${ }^{1}$, PAUL F. WILKINSON ${ }^{2}$ and DAVID F. \\ PENNER $^{3}$
}

\begin{abstract}
The results of analyses of rumen contents from 101 Peary caribou (Rangifer tarandus pearyi J. A. Allen 1902) collected on Banks Island are presented. Peary caribou on Banks Island were found to be versatile, broad spectrum grazers specializing on upland monocots, to ingest few lichens, and to exhibit significant seasonal and/or regional differences in diet.
\end{abstract}

RÉSUME. On présente les résultats des analyses du contenu des pans de 101 Peary caribous (Rangifer tarandus pearyi), rassemblés sur l'Ile de Banks. On a trouvé que ce caribou avait un régime alimentaire diversifié; il broute une gamme assez large de végétaux, en particulier les monocottes de montagne, ils mangent peu de lichens et montrent des differences significatives dans leur régime alimentaire saisonier et suivant les régions.

Traduit par Alain de Vendegies, Aquitaine Co. of Canada Ltd.

\section{INTRODUCTION}

Jonkel (1971) noted correctly that Peary caribou (Rangifer tarandus pearyi) of the Canadian Arctic Archipelago have been neglected by game managers and scientists; in particular, little information on their food habits is available. Analyses of rumen samples from 101 individuals shot on Banks Island between autumn 1972 and summer 1973 during an investigation of competition between musk oxen (Obivos moschatus Zimmermann) and Peary caribou (Wilkinson et al. 1976) are reported here.

\section{MATERIALS AND METHODS}

Rumen contents were analyzed from four groups of caribou: Sample I, 29 individuals collected near the confluence of the Muskox and Thomsen rivers between 18 and 20 March 1973; Sample II, 42 caribou shot in mid-August 1973 near the Thomsen River approximately $60 \mathrm{~km}$ south of its junction with the Muskox River; Sample III, 7 individuals taken near Jesse Bay on 26 October 1972; and Sample IV, 22 caribou collected on the Lennie River between 2 and 8 November 1972. Figure 1 shows the locations of the collection sites.

The rumen contents were collected and stored in the manner suggested by Martin and Korschgen (1963). Prior to analysis, each sample was washed through a bank of screens, and the residue collected on a screen of 200 meshes $/ 6.45 \mathrm{~cm}^{2}$. A random sample of 100 fragments per rumen was selected

\footnotetext{
'Faculty of Environmental Design, The University of Calgary, Calgary, Alberta T2N 1N4 'Suite 800, 1070 Bleury Street, Montreal, Quebec H2Z 1N3

${ }^{3}$ R.R. 3, Sherwood Park, Alberta T8A 3H3
} 


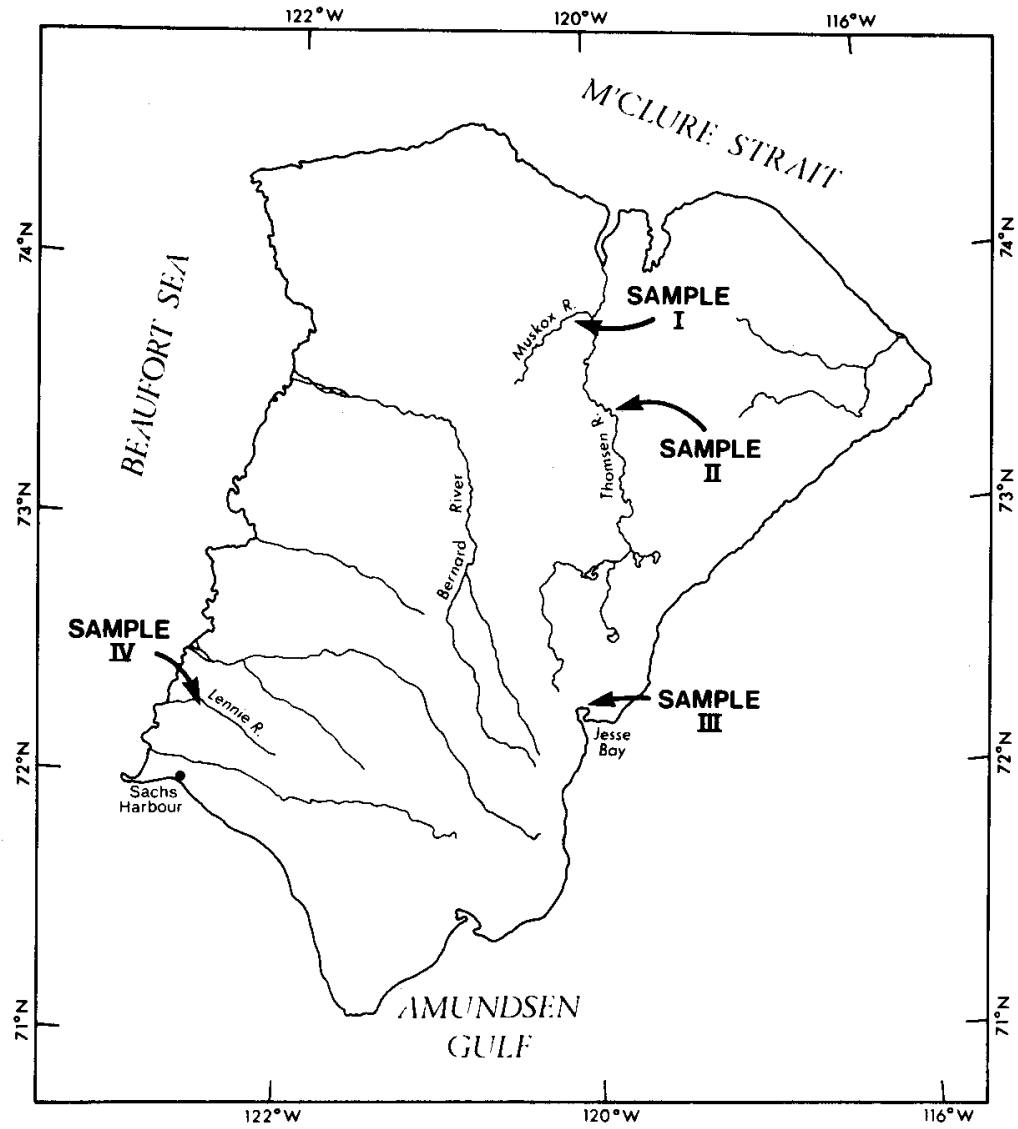

FIG. 1. Banks Island, N.W.T. depicting the locations of the four sites in which rumen samples were collected.

for identification from the material retained by the \#4 (mesh size $4.76 \mathrm{~mm}^{2}$ ) sieve by means of a point frame technique (Chamrad and Box 1964; Everitt and Drawe 1974). Each selected fragment was identified to genus and species if possible; otherwise, fragments were assigned to forage classes (grasses, sedges, forbs) or listed as unidentifiable. Genera and species of monocots were identified only casually.

Similarity indices (Gauch 1973) were used to compare the degree of similarity between samples:

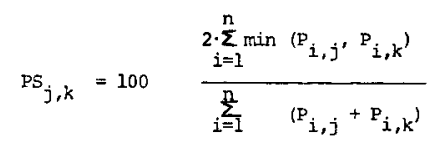

where $\mathrm{PS}_{\mathrm{j}, \mathrm{k}}$ is the percent similarity of the two diets for forage groups which are shared, $P_{i j}$ and $P_{i, k}$ are the percentages of forage $i$ in the samples $j$ and $k$, and where $\mathbf{n}$ is the number of forage classes shared. 
The diversity of the diet of each individual was inferred from the Shannon-Weaver diversity index (Poole 1974):

$$
H^{\prime}=-\left(\sum_{i=1}^{n} p_{i} \cdot \ln p_{i}\right)
$$

where $\mathrm{H}^{\prime}$ is the diversity of plant groups in each rumen, and $\mathrm{p}_{i}$ is the proportion of the $\mathrm{i}^{\text {th }}$ forage contained in the rumen, and $\mathrm{n}$ is the number of plant classes contained in the rumen. The average diversity of the diet in each Samples I, II, and IV was estimated as follows:

$$
\overline{\mathrm{H}}=\frac{\mathrm{H}_{1}^{\prime}+\mathrm{H}_{2}^{\prime}+\ldots \mathrm{F}_{\mathrm{n}}^{\prime}}{\mathrm{N}}
$$

where $\bar{H}$ is the mean diet diversity and $N$ is the number of rumens in the sample. Differences in the diversity of diet were tested by single-classification analysis of variance (Sokal and Rohlf 1969) at the 5\% level of probability.

Differences between samples in mean percentages of forage groups present were also tested at the $5 \%$ level of probability by single-classification analysis of variance after the sample variances had been equalized by an arcsin transformation. Sample III was excluded from the statistical analysis because of its small size $(\mathrm{N}=7)$ and large variances.

\section{RESULTS AND DISCUSSION}

\section{Description of Diet}

Table 1 summarizes the analysis results for the four samples. Monocots are by far the most important component in each of the four samples with grasses and sedges both comprising approximately equal proportions in all but Sample III. Table 2 lists the genera and species of grasses and sedges identified in the samples. This list cannot be considered as being comprehensive since identifications were not made systematically. Following monocots in importance are willows (Salicaceae) and the forbs Astragalus alpinus $L$. and Dryas integrifolia $M$. Vahl Lichens and mosses make up only a small fraction of the total diets. The findings of Deardon et al. (1975) indicate that the observed lack of lichens is unlikely to have been due to rapid digestion. They also state that mosses are nearly indigestible by caribou and therefore are usually over-represented in rumen contents. This would indicate that mosses are even less important in the diet of Peary caribou than is indicated in Table 1.

The only other major study of Peary caribou diet is that of Parker (1978) who utilized a microscopic analysis of cuticular and epidermal fragments in faeces and rumen contents. He found that for caribou on several high arctic islands, the summer diet consisted of 64-89\% Salix arctica Pall., 5-10\% forbs, 1-7\% Dryas integrifolia, and from 5-18\% monocots. By contrast, our summer data show more use of monocots and forbs and less use of Salix. Parker's winter diet data were taken from rumen samples preliminarily analyzed by 
TABLE 1. Contents of caribou rumens collected on Banks Island in 1972 and 1973.

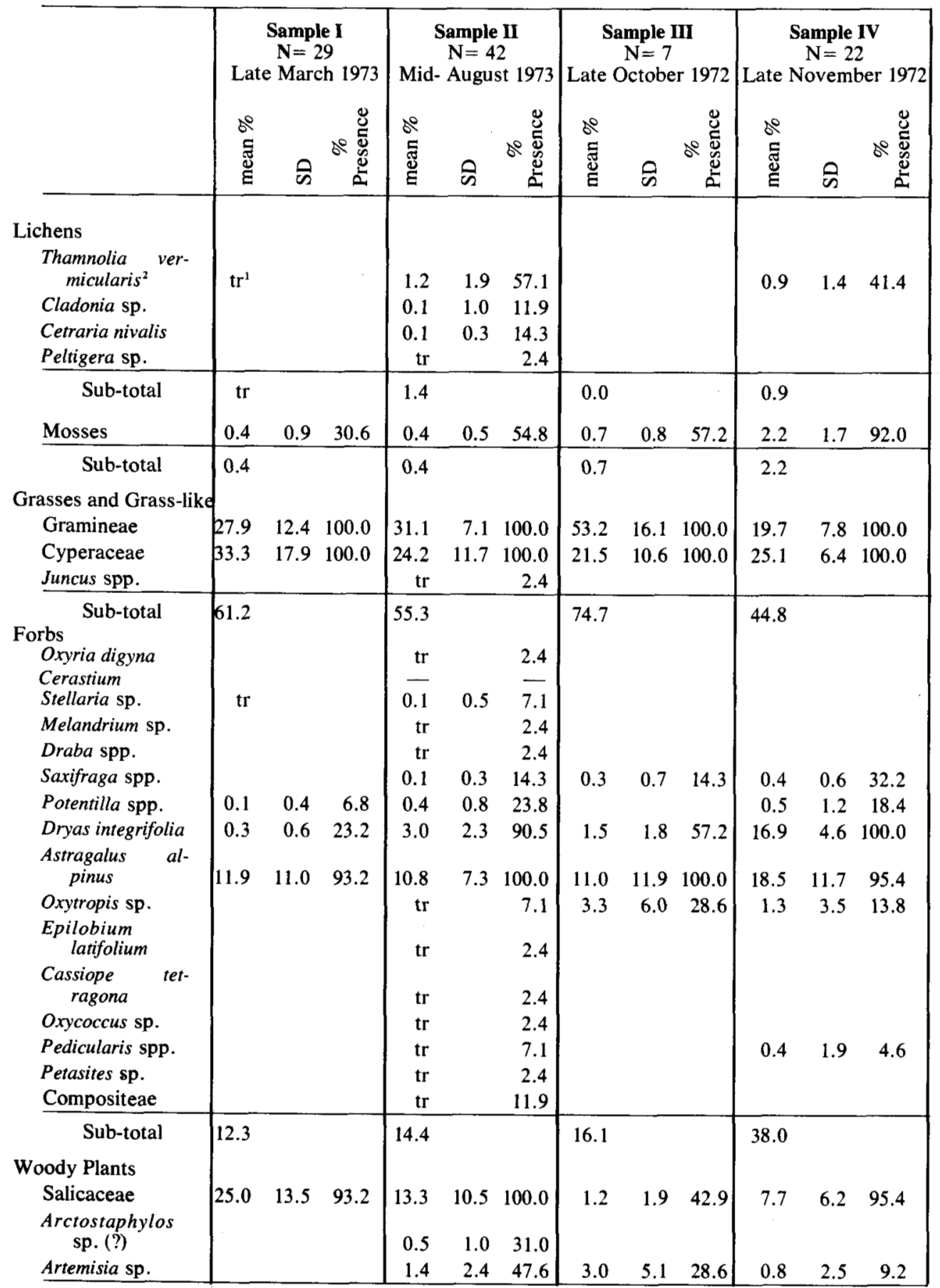


TABLE 1. Continued

\begin{tabular}{|c|c|c|c|c|c|c|c|c|c|}
\hline $\begin{array}{c}\text { Sub-total } \\
\text { Unidentified } \\
\text { dicot } \\
\text { Unidentified } \\
\text { roots }\end{array}$ & $\begin{array}{r}25.0 \\
0.9\end{array}$ & $2.5 \quad 20.4$ & $\begin{array}{r}15.2 \\
12.6 \\
\operatorname{tr}\end{array}$ & 7.7 & $\begin{array}{l}97.6 \\
11.9 \\
\end{array}$ & $\begin{array}{l}4.2 \\
4.5\end{array}$ & $3.9 \quad 71.5$ & $\begin{array}{l}8.5 \\
5.7\end{array}$ & 73.6 \\
\hline $\begin{array}{l}\text { TOTAL } \\
\text { Diversity Index } \\
\quad(\overline{\mathbf{H}})\end{array}$ & $\begin{array}{l}99.8 \\
1.13\end{array}$ & -3 & $\begin{array}{l}99.3 \\
1.63\end{array}$ & & & 100.2 & & $\begin{array}{l}100.1 \\
1.73\end{array}$ & \\
\hline
\end{tabular}

'tr indicates present in amounts less than $0.1 \%$.

'all plant names follow Porsild (1964).

${ }^{3}$ not done for Sample III.

TABLE 2. The grasses and sedges identified in the caribou rumens collected on Banks Island in 1972 and 1973.

\begin{tabular}{|c|c|c|c|c|}
\hline & Sample I & Sample II & Sample III & Sample IV \\
\hline Alopecurus alpinus & $n^{1}$ & $\mathbf{P}^{2}$ & $\mathbf{N}$ & $\mathbf{N}$ \\
\hline Deschampsia brevifolia & $\mathbf{P}$ & $\mathbf{P}$ & $\mathbf{N}$ & $\mathbf{N}$ \\
\hline Arctagrostis sp. & $\mathrm{N}$ & $\mathbf{P}$ & $\mathbf{N}$ & $\mathbf{N}$ \\
\hline Trisetum spicatum & $\mathbf{P}$ & $\mathrm{P}$ & $\mathbf{N}$ & $\mathbf{N}$ \\
\hline Poa spp. & $\mathbf{P}$ & $\mathbf{P}$ & $\mathbf{N}$ & $\mathbf{P}$ \\
\hline Festuca rubra & $\mathbf{P}$ & $\mathbf{N}$ & $\mathbf{N}$ & $\mathrm{N}$ \\
\hline Festuca brachyphylla & $\mathbf{P}$ & $\mathbf{P}$ & $\mathbf{P}$ & $\mathbf{N}$ \\
\hline Agropyron latiglume & $\mathbf{P}$ & $P$ & $\mathbf{N}$ & $\mathrm{N}$ \\
\hline Kobresia myosuroides & $\mathbf{P}$ & $\mathbf{N}$ & $\mathbf{N}$ & $\mathrm{N}$ \\
\hline Carex stans & $\mathbf{P}$ & $\mathbf{N}$ & $\mathrm{N}$ & $\mathbf{N}$ \\
\hline Carex spp. ${ }^{3}$ & $\mathbf{P}$ & $\mathbf{P}$ & $\mathbf{P}$ & $\mathbf{P}$ \\
\hline Luzula sp. & $\mathbf{P}$ & $\mathbf{N}$ & $\mathbf{N}$ & $\mathbf{N}$ \\
\hline
\end{tabular}

'Not recorded.

${ }^{2}$ Recorded.

${ }^{3}$ Several small, usually upland species of Carex.

Parker et al. (1975) and Thomas et al. (1976). His winter findings vary considerably from island to island and consist of $21-86 \%$ moss, $5-50 \%$ willow (wood and leaves), 4-25\% monocots, and 2-17\% forbs. By contrast, our winter data shows neligible use of moss and, like the summer diet, less Salix and more monocots and forbs than reported by Parker.

Parker (1978) concluded that during winter the physical condition of Peary caribou is positively correlated with willow intake and negatively correlated with moss intake while monocots and forbs exhibited no trend with physical condition. Our findings for Banks Island are somewhat enigmatic in this context as both willow and mosses were present in relatively low amounts together with a relatively large presence of monocots and forbs. Although it is of questionable validity to compare physical condition between populations by marrow content analysis (Dauphine 1971), the data reported by Wilkinson et al. (1976) tentatively suggest that Banks Island caribou collected during March 1973 were intermediate in physical condition in comparison with 
samples from other arctic islands reported by Parker et al. (1975) and Thomas et al. (1976). The relationship between winter diet and physical condition of Peary caribou may not, therefore, be as closely linked as was indicated by Parker (1978). Bergerud (1974), for example, suggested that caribou could be the most versatile grazers among North American cervid species. Peary caribou may then be quite capable of maintaining physical condition by adapting their grazing patterns to local conditions of forage availability.

Published analyses of the diet of barren ground caribou (R. $t$. tarandus) usually indicate a reliance on lichens for 30-60\% of the total intake (Scotter 1966; Deardon et al. 1975). This differs greatly from the $0-1.4 \%$ lichen presence noted in this study. Parker's (1978) analytical technique did not allow quantification of lichen in the diet but the results of Parker et al. (1975) and Thomas et al. (1976) both confirm the usually negligible quantities of lichen ingested by Peary caribou. The only exceptions are the $10+\%$ lichen presence in the Prince of Wales Island sample and the $32 \%$ content in the Melville Island sample reported by Thomas et al. (1975). As Parker (1978) has noted, the low standing crop of lichens in most high arctic areas precludes their use as a major food source.

\section{Seasonal Diet Differences}

The similarity index (PS) represents the percent similarity between two diets for the forage groups that are shared. Table 3 shows that all PS values are high but that the late March (Sample I) and mid-August (Sample II) diets were most similar (PS=79\%) while the late March (Sample I) and early November (Sample IV) diets were least alike (PS=67\%).

The Shannon-Weaver diversity index ( $\left.\mathrm{H}^{\prime}\right)$ indicates the variety and evenness of the forages present in the rumen. A high $H$ ' value indicates that a large number of species is being eaten in similar amounts and therefore implies that the animal is exploiting a broad food niche.

Table 3 presents the mean diversities $(\overline{\mathrm{H}})$ for Samples I, II, and IV. The diet of Peary caribou is least varied in late March $(\overline{\mathrm{H}}=1.13)$ and most varied in early November $(\overline{\mathrm{H}}=1.73)$ with summer occupying an intermediate position $(\bar{H}=1.63)$. Table 3 shows that only the differences between late March and mid-August and between late March and early November are statistically significant. As the rumen samples were collected in different areas as well as at different seasons, we cannot evaluate to what extent the observed diversity in diet is attributable to season rather than to spatial differences in forage availability.

Table 3 indicates several statistically significant between-sample differences in the use of forage classes, but, once again, it is uncertain whether they represent seasonal changes in preference or difference in the composition of the vegetation in the sample area. 
TABLE 3. Between-sample differences in mean percent presence of selected forage classes. Asterisks $\left(^{*}\right)$ indicate differences significant at the $5 \%$ level of probability.

\begin{tabular}{lccc} 
& $\begin{array}{c}\text { I vs II } \\
\text { Late March- } \\
\text { Mid- August }\end{array}$ & $\begin{array}{c}\text { I vs IV } \\
\text { Late March- } \\
\text { Early November }\end{array}$ & $\begin{array}{c}\text { II vs IV } \\
\text { Mid- August } \\
\text { Early November }\end{array}$ \\
\hline Monocots & $61.2-55.3$ & $61.2-44.8^{*}$ & $55.3-44.8^{*}$ \\
Salicaceae & $25.0-13.3^{*}$ & $25.0-7.7^{*}$ & $13.3-7.7^{*}$ \\
$\begin{array}{l}\text { Salicaceae + unident- } \\
\text { ified dicots }\end{array}$ & $25.9-25.9$ & $25.9-13.4^{*}$ & $25.9-13.4^{*}$ \\
Astragalus alpinus & $11.9-10.8$ & $11.9-18.5$ & $10.8-18.5^{*}$ \\
Dryas integrifolia & $0.3-3.0^{*}$ & $0.3-16.9^{*}$ & $3.0-16.9^{*}$ \\
Similarity Index $(\mathrm{PS})$ & $79 \%$ & $67 \%$ & $74 \%$ \\
Mean Diversity $(\overline{\mathrm{H}})$ & $1.13-1.63^{*}$ & $1.13-1.73^{*}$ & $1.63-1.73$
\end{tabular}

\section{CONCLUSIONS}

Three major conclusions emerge from our study: 1) Peary caribou on Banks Island do not eat large quantities of lichens or mosses at any season, 2) there are several significant seasonal and/or regional differences in diet of caribou on Banks Island, and 3) Peary caribou on Banks Island are versatile, broad spectrum grazers that concentrate at all seasons on upland monocots.

\section{ACKNOWLEDGEMENTS}

This study was undertaken as a contract awarded to LGL Ltd, Environmental Research Associates (101100 - 124 Street, Edmonton, Alberta T5N 1P6) by the Game Management Division of the Government of the Northwest Territories. We thank both organizations for financial and logistical support and for permission to publish our results. The Canadian Wildlife Service (Edmonton) kindly provided laboratory facilities. We acknowledge in particular the assistance of R. F. Schweinsburg (LGL Ltd.) and Mr. S. Miller (N.W.T. Game Management Division). E. Scheinberg (University of Calgary) gave statistical advice.

\section{REFERENCES}

BERGERUD, A. T. 1974. Decline of caribou in North America following settlement. Journal of Wildlife Management, 38:757-770.

CHAMRAD, A. D. and T. W. BOX. 1964. A point frame for sampling rumen contents. Journal of Wildlife Management, 28:473-477.

DAUPHINE, T. C. 1971. Physical variables as an index to condition in barren-ground caribou. Transactions of the North-east Section of the Wildlife Society, 28:91-108.

EVERITT, J. H. and D. L. DRAWE. 1974. Spring food habits of white-tailed deer in the South Texas plains. Journal of Range Management, 27:15-20.

DEARDON, B. L., R. E. PEGAU, and R. M. HANSEN. 1975. Precision of microhistological estimates of ruminant food habits. Journal of Wildlife Management, 39:402-407.

GAUCH, H. G., JR. 1973. The relationship between sample similarity and ecological distance. Ecology, 54:618-622.

JONKEL. C. J. 1971. Mammal research activities in the Arctic, 1970-1971. Arctic Circular, 21:16-19. 
MARTIN, A. C. and L. J. KorsChGEN. 1963. Food habits procedures. In: H. S. Mosby and O. H. Hewitt. (eds.), Wildlife Investigational Techniques. 2nd ed. Washington, D.C.: The Wildlife Society, Pages 320-329, in.

PARKER, G. R., D. C. THOMAS, E. BROUGhtON, and D. R. GRAY. 1975. Crashes of muskox and Peary caribou populations in 1973-1974 on the Parry Islands, Arctic Canada. Ottawa: Canadian Wildlife Service (Progress Note No. 56). 10pp.

PARKER, G. R. 1978. The diets of muskoxen and Peary caribou on some islands in the Canadian High Arctic. Ottawa: Canadian Wildlife Service (Occasional Paper No. 35). 21 pp.

POOLE, R. W. 1974. An Introduction to Quantitative Ecology. New York: McGraw-Hill.

PORSILD, A. E. 1964. Illustrated flora of the Canadian Arctic Archipelago. Ottawa: Natural History Museum of Canada (Bulletin No. 146). $218 \mathrm{pp}$.

SCOTTER, G. W. 1967. The winter diet of caribou in northern Canada. Canadian Field-Naturalist, 81:33-39.

SOKAL, R. R. and F. J. ROHLF. 1969. Biometry: The Principles and Practice of Statistics in Biological Research. San Francisco: W. H. Freeman. 776 pp.

THOMAS, D. C., R. H. RUSSELL, E. BROUGHTON, and P. L. MADORE. 1976. Investigations of Peary caribou populations on Canadian arctic islands, March-April 1975. Ottawa: Canadian Wildlife Service (Progress Note No. 64). 13 pp.

WILKINSON, P. F., C. C. SHANK, and D. E. PENNER. 1976. Muskox-caribou summer range relations on Banks Island, N.W.T. Journal of Wildlife Management, 40:151-162. 